\title{
Too masculine for healthcare, too feminine for intense sports: Correlation between gender conformity and pro-health behaviours
}

Authors' Contribution: A Study Design

B Data Collection

C Statistical Analysis

D Data Interpretation

E Manuscript Preparation

F Literature Search

G Funds Collection

\author{
Aleksandra Pawłowska ${ }^{1 \text { ABCDEF }}$, Kornelia Lipowska ${ }^{\text {ACEFG }}$, Daniel Krokosz ${ }^{1}$ CDE \\ ${ }^{1}$ Gdansk University of Physical Education and Sport, Gdansk, Poland \\ 2 Department of Psychology, Faculty of Social and Behavioural Sciences, \\ University of Amsterdam, the Netherlands
}

\section{abstract}

Background:

Material and methods:

Results:

Conclusions:

Key words:

The goal of this paper is to examine to what extent levels of femininity and masculinity are associated with practicing several types of health behaviours among individuals who are physically active and inactive.

A total of 559 individuals aged between 35 and $45(M=39.4 ; S D=3.2)$ took part in the study. The inactive group consisted of 211 individuals ( $n=85$ women, $n=126$ men), and the active group consisted of 348 individuals ( $n=131$ women, $n=217$ men). The participants completed the following pen-andpaper questionnaires: the Psychological Gender Inventory, the Health Behaviours Inventory, and the Inventory of Physical Activity Objectives. of health behaviours in men and women. Among men, femininity turned out to be a factor protective against hegemonic masculinity, while among women it was observed that it is mainly masculinity that correlates with health behaviours. Physical activity was associated with a better psychological attitude.

It is possible to treat physical activity as a protective factor against decreased mood and an aid in coping with decreased mood. Society and culture should encourage the development of femininity and masculinity from the earliest years. Future research on masculinity and femininity and pro-health behaviours should be aimed at looking for ways to promote physical activity among undifferentiated individuals.

\section{article details}

Article statistics:

Full-text PDF:

Copyright

Indexation:

Funding:

Conflict of interests:

Corresponding author:

Open Access License:

Word count: 4,900; Tables: 2; Figures: 0; References: 110

Received: July 2021; Accepted: September 2021; Published: September 2021

http://www.balticsportscience.com

(c) Gdansk University of Physical Education and Sport, Poland

Celdes, Clarivate Analytics Emerging Sources Citation Index (ESCI), CNKI Scholar (China National Knowledge Infrastructure), CNPIEC, DOAJ, EBSCO - Central \& Eastern European Academic Source, EBSCO - SPORTDiscus, EBSCO Discovery Service, Google Scholar, Index Copernicus, J-Gate, Naviga (Softweco, Primo Central (ExLibris), ProQuest - Family Health, ProQuest - Health \& Medical Complete, ProQuest - Illustrata: Health Sciences, ProQuest Nursing \& Allied Health Source, Summon (Serials Solutions/ProQuest, TDOne (TDNet), Ulrich's Periodicals Directory/ ulrichsweb, WorldCat (OCLC)

This research received no specific grant from any funding agency in the public, commercial, or not-for-profit sectors. Authors have declared that no competing interest exists.

Dr Daniel Krokosz; Gdansk University of Physical Education and Sport, Department of Psychology, Gorskiego 1 Str. 80-336 Gdansk, Poland, e-mail daniel.krokosz@awf.gda.pl

This is an open access article distributed under the terms of the Creative Commons Attribution-Non-Commercial-NoDerivatives 4.0 International (https://creativecommons.org/licenses/by-nc-nd/4.0/), which permits use, distribution and reproduction in any medium, provided the original work is properly cited, the use is non-commercial and is otherwise in compliance with the license. 


\section{INTRODUCTION}

\section{GENDER STEREOTYPES AND PRO-HEALTH BEHAVIOURS}

We learn how to take care of our health throughout our lives. Every age is characterised by different needs and attitudes towards health behaviours. One of the tipping points in life is the midlife crisis that occurs between the ages of 35 and 50 [1]. At this point, people ask themselves fundamental questions regarding their past and their future. They often change the way they approach the world and reorganise their lives and priorities [2]. Another change associated with the midlife crisis is the acquisition of features typically associated with the other gender. For instance, women become more strict and assertive [3]. At the same time, there is the "cult of youth and beautiful bodies" in society [4]. Because of that, women may exhibit behaviours such as dieting, becoming physically active, or undergoing plastic surgery [5]. Physical activity and maintaining appropriate body mass are factors that make it easier to get through this crisis and accept the changes [6, 7]. Given the volume and significance of the changes that take place in this period of life, it seems worthwhile in this context to explore levels of self-care through engaging in pro-health behaviours and behaviours considered feminine or masculine.

Gender stereotypes, as a collection of socially accepted beliefs regarding the mental characteristics of men and women as well as activities appropriate to each gender [8], categorise many behaviours as either feminine or masculine. For instance, there exist many stereotypes in different societies that characterise women as taking better care of their health, eating healthier, being quicker to react to illness, and being more caring [9-11]. On the other hand, men are more likely to be associated with unhealthy behaviours, such as smoking tobacco or drinking alcohol [12,13], which can be perceived as symbols of masculinity [1416], and some researchers directly associate masculinity with harmful alcohol use [16-18]. This would suggest that women engage in more pro-health behaviours than men do. On the other hand, sport, a perfect example of an area with very strong stereotypes, is usually described as "masculine" [19, 20]. For women, taking part in competitive sports might be seen as incongruent with female gender roles, which applies most of all to disciplines such as boxing, football, or judo [21, 22]. Acting incongruently with gender roles may lead to a sense of gender role insecurity and hence to undertaking behaviours aimed at reinstating stability $[23,24]$.

A study on a group of 392 individuals aged 17-20 also revealed low levels of pro-health behaviours. The authors concluded that this result suggests a decline in the lifestyle of youth in Poland [25]. Similar observations were made by Walentukiewicz et al. [26], as well as Michalski et al. [27] regarding 18-year-olds. Interestingly, the observations of Nowak and Barcicka [25] suggest that men engage in more pro-health behaviours, while other authors report that this is characteristic of women [27].

Research conducted in 2013 on nurses [28] does not support the stereotype about women taking care of their health. In addition to the participants being female, they were also students in the area of medicine. However, the surveys revealed that women aged 18-21 presented average levels of pro-health behaviours, with many individuals scoring low results. Other authors also reported low levels of pro-health behaviours in this social group [29].

A study on students confirmed that the more active an individual is, the higher they score on pro-health behaviours, but it also supported the stereotype that women take better care of themselves [30]. In turn, Zalewska-Puchała et al. [31] reported that students of the AGH University of Science and Technology in Kraków were characterised by average levels of pro-health behaviours and exhibited risky behaviours. A particular gender difference was revealed in terms of alcohol use. Men drank alcohol significantly more frequently. Moreover, women's diets turned out to be much more rational. 
Another study, conducted on a group of individuals aged above 60, revealed a relatively high level of pro-health behaviours [32]. The authors did not note significant differences between men and women. Yet another study on the same age group again revealed an above-average level of pro-health behaviours, with gender being a differentiating factor: women had significantly higher scores [33]. A different study on individuals aged over 60 showed a statistically significant difference between men and women only in the case of eating habits (with women exhibiting better eating habits than men). The author concluded that this may be an indication of positive changes in men's attitudes toward taking care of their own health [34].

As shown by the studies discussed above, gender can differentiate levels of pro-health behaviours, but does not necessarily do so. As one may experience gender identity threat when undertaking behaviours/actions that are incongruent with gender stereotypes [35], we may expect to observe different levels and kinds of pro-healthy behaviours among men and women.

\section{EATING HABITS}

Research by Gacek [36] on a group of physicians revealed relatively low scores for good nutrition and physical activity. Women scored better in terms of BMI and nutrition. In a study by Rothgerber [37], it was noted that men eat more meat, especially red meat, and women are more likely to select vegetarian meals. The author also suggests that eating meat is directly associated with masculinity. In the context of eating disorders, researchers lean towards stating that they occur more frequently among women [38-42]. A link between eating disorders and gender norms for women can be seen in the desire for a slim body [4345]. However, reports about eating disorders in men and their association with femininity and masculinity are also worth noting. Research by Griffiths et al.[46] suggests that levels of masculinity and femininity are associated with disorders such as muscle dysmorphia, while femininity is also positively correlated with eating disorders related to reducing one's body mass. Cella et al.[47] reported that feminine participants exhibited higher levels of disordered eating behaviours than masculine, androgynous, or undifferentiated individuals did.

\section{PREVENTIVE BEHAVIOURS}

Men's knowledge about health and disease as well as their willingness to undergo screening for cancer is significantly lower than that of women [48]. This might be caused by traditional perceptions of what 'being manly' means [49]. Moreover, some preventive screenings - such as prostate examination or colonoscopy - are perceived as an attack on one's masculinity, and thus gender role attitudes may make it harder for men to be willing to undergo regular check-ups [50]. However, this does not hold for war veterans, for whom one study did not reveal any relationship between masculinity beliefs and colorectal cancer screening adherence or colonoscopy [51]. However, the authors themselves pointed out that this group constitutes a very particular subset of men, and more studies on other social groups are needed. There are also reports that associate masculinity with seeking help. One such study concerned firemen who take care of their health in order to ensure they are able to serve and help people [52]. The same study included young men who claimed that they do not want to bother their physicians with trivial problems and they only seek help when something really serious happens, because it is their perception that that is how a man should behave. Masculinity can be beneficial for health, but untempered masculinity may be associated with risk behaviours and higher death rates [53].

Research related to cardiovascular diseases showed that, independently of biological sex, individuals scoring high on femininity [54] have a higher probability of recurrence of acute coronary syndrome or major adverse cardiovascular events $[55,56]$. It was also found that 
women, in comparison to men, are less likely to avail themselves of cardiological care as a preventive measure. This is caused by underestimating risk [57].

Respiratory tract infections are caused by contact with microbes via droplets. Naturally, the first preventive measure is washing one's hands. Research has shown that men are less eager to wash their hands and less likely to use soap and water. A similar tendency has been observed in medical workers. It could be inferred that this is associated with genderassociated factors in maintaining hygiene $[58,59]$.

\section{HEALTH PRACTICES}

Many adults sleep less than the recommended 7 hours [60, 61]. Preliminary results from one study suggest that, among men, time spent sleeping is inversely correlated with how masculine they are perceived by society. Men who sleep less are perceived as more agentic and thus more masculine. No such correlations were observed in the case of women. Men perceiving themselves as more masculine also correlates with self-reports of sleeping less than is recommended. Results suggest that less sleep is attributed to people who are generally more masculine, independently of biological sex [61]. It has also been reported that women sleep more, but that their quality of sleep is poorer [62,63]. Gender differences between the amount and quality of sleep are often explained through differences in types of jobs, ways of spending free time, and taking care of children and family [62].

Physical activity is a health practice that takes care of both body and mind [64]. Intense physical activity positively affects stress management in adolescents [65]. Moreover, children participating in physical activities have better cognitive capacities, as indicated by improved ability to focus attention, faster development of speech, and better executive functions in general [66].

Despite the fact that physical activity is beneficial for everyone, it is dominated by men [67, 68]. This is partially because the feminine gender role is linked with the caregiver role, and eventually, due to the lack of time, women withdraw from additional activities, making their physical activity irregular at best [69]. The choice of a particular sport is also linked with masculinity and femininity. Sports which include physical contact, confrontation, power, and aggression are considered masculine, and those dominated by expression, grace, and aesthetics are considered feminine [70]. Masculine men - i.e. those sex-typed, in contrast to those sexually undifferentiated - and androgynous men are significantly less likely to participate in sports perceived as feminine. Sex-typed women are much less likely to undertake masculine sports than androgynous and cross-sex-typed women [71]. Mroczkowska [22] suggests that women who practice sports that are perceived as "masculine" are more likely to be of the androgynous or masculine types than are inactive women.

Research by Burdzicka-Wołowik [72] suggests that there is the least amount of androgynous women among those who do not do any sports and the most among those who practice sports. The same is the case for cross-sex typed women. There was not a single sex-typed woman in the group that practised judo, boxing, and wrestling. The group doing non-masculine sports was comprised mostly of androgynous women. Among physically active individuals, feminine women were the smallest group. The opposite was the case for inactive individuals. Results of a study from 2016 revealed that women who practice aesthetic sport disciplines do not differ from those partaking in masculine sports in terms of their body esteem or psychological gender. In both groups, androgynous women were a majority, followed by masculine women [73]. Other studies have also observed that sports without differentiation into masculine and feminine disciplines are most likely to be undertaken by androgynous individuals [74]. It is a similar situation for women who partake in team sports; however, in the case of men, the sex-typed type dominates [75]. 


\section{POSITIVE MENTAL ATTITUDE}

Women have problems with physical and mental health significantly more frequently than do men [53, 76]. One of the reasons for this is ways of coping with stress and of perceiving stressors [53]. Women are stereotypically considered to be more emotional and to have a greater propensity to express sadness, fear, and sympathy [77]. Moreover, women perceive stress as a threat rather than as a challenge, and are more prone to experience chronic stress [78]. Stress may induce various somatic symptoms, such as stomach pain, as well as serious illnesses such as cancer [79, 80]. Chronic stress may lead to many chronic diseases [81, 82]. Individuals who are stressed frequently and intensely are at risk of depression and psychosis [83, 84]. Research by Lipińska-Grobelny [85] suggests that masculinity and femininity positively correlate with task-oriented methods of coping with stress. Masculinity negatively correlates with emotion-oriented coping. Cross-sexed women and androgynous individuals, with an emphasis on men, are more likely to use the task-oriented style. The task-oriented style in turn negatively correlates with depression, distress, and anxiety. Feminine women use emotion-oriented strategies more often. Research on first-year students revealed correlations suggesting that strategies of coping with stress that are focused on tasks as well as those focused on avoidance are positively correlated with optimism and satisfaction with life. On the other hand, being emotion-oriented negatively correlates with these factors [86]. A study from 2010 showed that self-esteem and optimism levels in youth living in the countryside is higher for boys than for girls [87].

In line with the statement that women fall ill more frequently, a majority of people suffering from depression are female [88, 89]. In research by Szpitalak and Prochwicz [90] on depressed individuals, the majority were sexually undifferentiated and sex-typed women. These women also experienced the most severe symptoms of depression. Among depressed men, the dominant types were undifferentiated and feminine. Androgynous and masculine men were characterised by much less severe mood disorders. This research suggests that the masculine type in women and men fosters the best mental health.

Men are often unwilling to look for psychological help because they believe that a man should be stoic, and a therapist would require them to open up [91]. Research has shown that heterosexual men who seek help for depression are assessed as more feminine than those who do not seek help. However, when a man is gay, he will be assessed as more feminine regardless of whether he looks for help when he is ill. In any case, this situation does not increase or decrease perceived masculinity. Strong attachment to the traditional understanding of masculinity has been linked with a lack of willingness to seek help for mental disorders [92].

\section{THE GOAL OF THE STUDY}

The goal of the current study was to verify whether levels of masculinity and femininity correlate with health behaviours among physically active and inactive individuals.

\section{MATERIAL AND METHODS}

\section{PARTICIPANTS}

In order to investigate the relationship between levels of masculinity and femininity and health behaviours, a group of 599 individuals aged between 35 and $45(M=39.4 ; S D=3.2)$ was studied. This age range is typically associated with entering the mid-life crisis [1]. Moreover, the group was divided into physically active and inactive individuals. The inactive group consisted of 211 individuals ( $n=85$ women, $n=126$ men). The physically active group consisted of 348 individuals ( $n=131$ women, $n=217$ men). The division into groups was made based on the World Health Organization guidelines [93]. They recommend regular 
moderate level physical activity of at least 150-300 minutes a week, or about 75-150 minutes a week if the level of intensity is high. Both the moderate and high intensity exercises are considered appropriate. Moreover, it is recommended to do strength exercises at least twice a week, with moderate and high intensity. Participants only underwent one measurement.

\section{MeAsuRement Methods}

The study was conducted using the Psychological Gender Inventory [94], the Health Behaviours Inventory [95], and the Inventory of Physical Activity Objectives [96].

The Psychological Gender Inventory (IPP) from Kuczyńska's [94] study is the Polish equivalent of the Sex-Role Inventory by Bem [97]. It consists of 35 features that the respondent indicates to what extent each applies to them on a 5-point scale. The inventory consists of 15 male, 15 female, and 5 neutral traits and thus reflects cultural stereotypes of men and women, creating a scale of femininity and masculinity [94].

The Health Behaviours Inventory (IZZ) by Juczyński [95] consists of 24 statements that describe various health behaviours. Behaviours are classified into proper eating habits, preventive behaviours, positive mental attitudes, and health practices. The scale consists of five responses: almost never, rarely, occasionally, often and almost always, which are assigned a score from 1 to 5 . The overall score for the severity of health-related behaviours is between 24 and 120 points. Higher results indicate that the respondent exhibits more behaviours that positively influence their health. The results are converted to a genderadjusted sten scale.

The Inventory of Physical Activity Objectives (IPAO) by Lipowski and Zaleski [96] is used to define the motivational function of the goal of physical activity. The questionnaire is composed of questions relating to the type, volume, and frequency of physical activity undertaken as well as socio-demographic determinants. The respondents also answer questions on participation in competitive sports (in the past and at present) and their passive participation in sports, for example as fans or spectators. The 12 questions and statements described are classified on a Likert scale (1-5). The second part of the questionnaire specifically addresses the motivational function of the physical activity goal. The questions concern the motivational value, time management, persistence in action and motivational conflict. Additionally, the IPAO makes it possible to define the multidimensionality of goals. Raw results are converted to sten values [98]. The questionnaire has acceptable psychometric properties. Cronbach's reliability coefficient is at the level of 0.78 [96].

\section{RESULTS}

The results of the analyses revealed a relationship between health behaviours, physical activity, and psychological gender. Using analysis of variance, it was established that there are differences between men and women who are physically active and inactive in terms of eating habits, preventive behaviours, psychological attitudes, and health practices (Table 1).

Post-hoc Tukey tests for various Ns revealed that women who are physically active do not differ in levels of masculinity from men who are physically active $(p=0.077)$. The situation is analogous for physically inactive groups $(p=0.533)$. In the case of eating habits, physically active women had a significantly higher average than inactive women $(p=<0.001)$, inactive men $(p=<0.001)$, and active men $(p=<0.001)$. On the other hand, men who are active differ from inactive men $(p=0.004)$, but not from inactive women $(p=0.500)$. It seems that physical activity is a factor that is associated with good nutritional choices and which further encourages these choices. It can also be seen that women are more likely to pay attention to their nutrition, even if they are not regularly physically active. Active women scored significantly higher on preventive behaviours than inactive men $(p=<0.001)$, active men 
( $p=0.022)$, and inactive women $(p=0.042)$. Women undergo preventive medical tests more frequently and they are more likely to engage in activities that protect them from worsening of their health. Physical activity may be a factor pushing them towards even more frequent and more intense prevention, or just serve as one preventive factor [99]. The average psychological attitudes of men and women who are active was not statistically different $(p=0.222)$, the same concerns the inactive groups $(p=0.993)$. There were no differences between groups in health practices.

Table 1. Intergroup differences in pro-health behaviours, masculinity, and femininity

\begin{tabular}{|c|c|c|c|c|c|c|c|c|c|c|c|}
\hline \multirow{2}{*}{ Attribute } & \multicolumn{2}{|c|}{ 아 $\mathrm{AF}$} & \multicolumn{2}{|c|}{ @ nAF } & \multicolumn{2}{|c|}{$\sigma^{\pi} \mathrm{AF}$} & \multicolumn{2}{|c|}{$\sigma^{\pi} \mathrm{nAF}$} & \multicolumn{3}{|c|}{ Differences } \\
\hline & $M$ & $S D$ & M & $S D$ & M & $S D$ & $M$ & $S D$ & & $F$ & $P$ \\
\hline \multirow{2}{*}{ Feminity } & \multirow{2}{*}{56.58} & \multirow{2}{*}{6.56} & \multirow{2}{*}{54.44} & \multirow{2}{*}{5.88} & \multirow{2}{*}{52.52} & \multirow{2}{*}{7.00} & \multirow{2}{*}{49.99} & \multirow{2}{*}{7.52} & ㅇ vs $0^{x}$ & 49.80 & $<0.001$ \\
\hline & & & & & & & & & AF vs nAF & 15.77 & $<0.001$ \\
\hline \multirow{2}{*}{ Masculinity } & \multirow{2}{*}{49.75} & \multirow{2}{*}{8.87} & \multirow{2}{*}{46.28} & \multirow{2}{*}{8.07} & \multirow{2}{*}{52.14} & \multirow{2}{*}{7.94} & \multirow{2}{*}{47.95} & \multirow{2}{*}{7.44} & ᄋ vs $0^{x}$ & 9.10 & 0.003 \\
\hline & & & & & & & & & AF vs nAF & 30.71 & $<0.001$ \\
\hline \multirow{2}{*}{ Eating habits } & \multirow{2}{*}{22.02} & \multirow{2}{*}{4.27} & \multirow{2}{*}{18.82} & \multirow{2}{*}{4.66} & \multirow{2}{*}{19.79} & \multirow{2}{*}{4.41} & \multirow{2}{*}{17.87} & \multirow{2}{*}{4.85} & @ vs $0^{\pi}$ & 19.66 & $<0.001$ \\
\hline & & & & & & & & & AF vs nAF & 37.78 & $<0.001$ \\
\hline \multirow{2}{*}{$\begin{array}{l}\text { Preventive } \\
\text { behaviours }\end{array}$} & \multirow{2}{*}{21.15} & \multirow{2}{*}{4.12} & 1941 & 409 & 3 & 1 & 0 & 1 & q vs $0^{\circ}$ & 12.50 & $<0.001$ \\
\hline & & & 19.41 & 4.07 & כ & 4.44 & 10.40 & 4.41 & AF vs nAF & 14.42 & $<0.001$ \\
\hline Psychological & 2250 & 345 & 2006 & 388 & 2164 & 372 & 2021 & 367 & q vs $0^{x}$ & 2.22 & 0.137 \\
\hline & & & & & 21.04 & 0.12 & 20.21 & 0.01 & AF vs nAF & 32.30 & $<0.001$ \\
\hline Health & 1989 & 4.02 & 18.45 & 4.45 & 18.94 & 3.69 & 18.80 & 3,45 & ○ vs $0^{x}$ & 1.80 & 0.180 \\
\hline bel & & & & & & & & & AF vs nAF & 3.79 & 0.052 \\
\hline
\end{tabular}

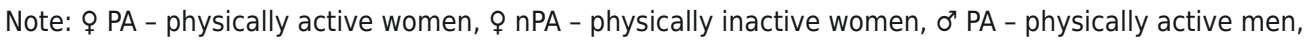
$\sigma^{7} \mathrm{nPA}$ - physically inactive men

The next step of the statistical analyses was to check for statistically significant correlations between femininity, masculinity, and pro-health behaviours in all groups. Among physically active women, statistically significant correlations occurred only between femininity $(r=0.29$; $p=0.001)$, masculinity $(r=0.31 ; p=<0.001)$, and psychological attitude. In inactive women, a correlation between masculinity and psychological attitude $(r=0.32 ; p=0.003)$ as well as eating habits $(r=0.34 ; p=0.002)$ was observed. In this group, femininity was not significantly correlated with health behaviours.

Table 2. Correlations between pro-health behaviours and masculinity/femininity among active and inactive persons

\begin{tabular}{|c|c|c|c|c|c|c|c|c|}
\hline & \multicolumn{2}{|c|}{ Eating habits } & \multicolumn{2}{|c|}{ Preventive behaviours } & \multicolumn{2}{|c|}{ Psychological attitude } & \multicolumn{2}{|c|}{ Health behaviours } \\
\hline & $r$ & $p$ & $r$ & $P$ & $r$ & $p$ & $r$ & $P$ \\
\hline & \multicolumn{8}{|c|}{ Physically active women } \\
\hline Masculinity & 0.14 & 0.101 & 0.16 & 0.076 & 0.31 & $<0.001$ & 0.21 & 0.810 \\
\hline \multirow[t]{2}{*}{ Feminity } & 0.13 & 0.139 & -0.03 & 0.712 & 0.29 & 0.001 & 0.15 & 0.092 \\
\hline & \multicolumn{8}{|c|}{ Physically inactive women } \\
\hline Masculinity & 0.34 & 0.002 & 0.21 & 0.051 & 0.32 & 0.003 & 0.20 & 0.073 \\
\hline \multirow[t]{2}{*}{ Feminity } & 0.05 & 0.683 & 0.05 & 0.622 & 0.04 & 0.702 & 0.05 & 0.625 \\
\hline & \multicolumn{8}{|c|}{ Physically active men } \\
\hline Masculinity & 0.35 & $<0.001$ & 0.25 & $<0.001$ & 0.43 & $<0.001$ & 0.31 & $<0.001$ \\
\hline \multirow[t]{2}{*}{ Feminity } & 0.26 & $<0.001$ & 0.29 & $<0.001$ & 0.47 & $<0.001$ & 0.30 & $<0.001$ \\
\hline & \multicolumn{8}{|c|}{ Physically inactive men } \\
\hline Masculinity & 0.30 & 0.001 & 0.24 & 0.007 & 0.31 & $<0.001$ & 0.26 & 0.003 \\
\hline Feminity & 0.33 & $<0.001$ & 0.36 & $<0.001$ & 0.30 & 0.001 & 0.20 & 0.026 \\
\hline
\end{tabular}


In the group of physically active men, both masculinity and femininity had the strongest correlations with psychological attitude $(r=0.43 ; p=<0.001$, and $r=0.47 ; p=<0.001$, respectively). Among the physically inactive men, preventive behaviours were the strongest correlate of femininity $(r=0.36 ; p=<0.001)$ and psychological attitude was the strongest correlate of masculinity $(r=0.31 ; p=<0.001)$. The remaining health behaviours also positively correlated with these variables, but to a lesser extent.

\section{DISCUSSION}

Among both men and women, higher levels of masculinity and femininity were found to be associated with better results in most categories related to pro-health behaviours. Research by Palacz [30] on students also supported the claim that physical activity is associated with levels of pro-health behaviours. Similarly, positive correlations between being active and activities related to health have been observed by Boguszewski et al. [100], Litwic-Kaminska and Izdebski [101], as well as Delisle et al. [102]. Their research suggests that individuals who exercise also consider pro-health choices important in other aspects of life and are less likely to engage in risky behaviours. In our research, pro-health practices were the only category in which there was no significant difference between the groups. A similar phenomenon was observed by Michalski et al. [27], who found that women did not score higher than men only on pro-health practices. This is a surprising result, because physical activity is a pro-health behaviour and so the natural expectation would be that physically active individuals would score higher. It is possible that inactive individuals pay more attention to the quality and amount of sleep or that they have more time to rest due to not having regular training sessions. It sometimes happens that physically active individuals neglect recovery and drive themselves into various kinds of disorders or overtraining [103].

It is worth emphasizing that the results clearly indicate positive correlations between physical activity and good psychological attitude among both men and women. Based on the current research, as well as studies by other authors, it is possible to state that it is worthwhile encouraging individuals with decreased mood to engage in various forms of physical recreation, and it is possible to treat physical activity as a method of prevention against decreased mood, depression and the consequences of such states [104, 105]. Thanks to the correlation analyses, it was also observed that masculinity is positively correlated with psychological attitude in each of the studied groups. This is in line with research by [90] Szpitalak and Prochowicz [90], who showed that the masculine type of psychological gender is associated with mental health. Many researchers have concluded that masculinity is the variable that ensures mental health, not femininity. This is why they do not report advantages in this area in androgynous individuals [106]. In turn, Bem [54, 97] stated that it is androgynous individuals who have the widest spectrum of behaviours, which is why they have the best ability to adapt, while on the other side of the continuum there are the undifferentiated individuals who have the greatest problems with adaptation. The results of the study by Juster et al. [107] are partially in line with this. Among the participants in their study, androgynous men were protected from allostatic load while women were not. Higher femininity was associated with higher allostatic load. In the context of stress, Lipińska-Grobelny [85] concluded that masculinity and femininity are positively correlated with task-oriented coping, which is the most efficient and the most beneficial for the mental health of an individual.

Correlation analyses revealed that among both physically active and inactive men, all health behaviours are positively associated with both femininity and masculinity. This means that the androgynous type of psychological gender increases the chances of engaging in pro-health behaviours. It is possible that, in this case, femininity protects one from untempered masculinity and gender roles, allowing for, e.g., regular examinations or seeking 
psychological help. Correlations of femininity and masculinity observed in the group of physically active women indicate that these factors are only important in the context of psychological attitude. This result to some extent supports the research by Bem [54, 97], who believed that androgynous individuals adapt better. It is worth emphasizing that there are studies reporting that typically 'masculine' sports are dominated by androgynous and cross-sex typed women and that androgynous women dominate in other sports [22, 7275]. It is possible that their high results on femininity and masculinity grant them better mental coping skills, and sport was one of the factors that led them to being characterised by higher femininity and masculinity. Among physically inactive women, only masculinity correlated with psychological attitude and eating habits. The first correlation supports the aforementioned research from other authors. The positive relationship with eating habits may indicate that masculinity protects women from eating disorders, which are associated with feminine gender norms $[42,108]$ and instead directs them towards good nutritional choices, even despite a lack of regular physical activity. Based on their research, Cella et al. [47] directly stated that the feminine personality type may increase one's chances of developing eating disorders.

\section{CONCLUSIONS}

1. Physical activity supports pro-health choices among both men and women. The positive relationship with mental attitude is particularly visible. One should treat physical activity as something that supports good mental health and prevents decreased mood. Thus, it can be promoted by making society aware of these benefits.

2. We should take care to support boys and then men in developing appropriate levels of femininity, which will protect them from hegemonic masculinity. On the other hand, in the case of girls and women, masculinity should be supported as a factor positively associated with mood. For instance, from the earliest years of childhood both girls and boys should be allowed to do things considered stereotypically appropriate for the opposite sex, thereby fostering adequate levels of both masculinity and femininity. A possible way of doing this would be by letting children play with the toys stereotypically considered appropriate for the opposite sex. Toys designed for girls are often associated with caring and socializing, whereas those for boys send messages related to aggression, violence, and heroism [109]. A way of expanding children's spectrum of accessible toys, regardless of the child's gender, would be by providing counter stereotypical gender-typed implicit labels, for example by using counter-stereotypical colours [109]. For instance, the LEGO ${ }^{\circledR}$ Corporation has released a collection with pink bricks that match girls' preferences regarding toys, thus encouraging them to play with counter stereotypical toys. It is also important to show and promote examples of appropriate behaviour in social media, social campaigns, and to make parents aware of the potential detrimental effects of teaching children double standards for boys and girls.

3. One should consider how to help individuals whose femininity and masculinity levels are low with all health related behaviours, in order to help them take better care of their physical and mental health. A good way of doing this would be promoting physical activity using more gender neutral terms, avoiding terms particularly appealing to one gender (e.g., "healthy" for women or "strong/well built" for men). For instance, regular physical activity can be promoted by spreading the knowledge that it might increase life expectancy by up to even seven years [110]. Such a way of promoting increased physical activity will reach not only people with high levels of femininity and masculinity but also those with lower levels of these factors. 


\section{LIMITATIONS}

These analyses are not free from certain limitations. The relatively narrow age range does not allow for the results to be generalised to other age groups. Future research should also take into account whether the respondent has children and their ages as well as the respondent's occupation and how much free time they have. These are important factors that might allow for a wider perspective, especially with regards to health-related practices. Comparisons with other age groups could also provide additional information.

\section{REFERENCES}

[1] Piotrowski K, Brzezińska AI, Pietrzak J. Four statuses of adulthood: adult roles, psychosocial maturity and identity formation in emerging adulthood. Health Psychol Rep. 2013;1(1):52-62. https://doi.org/10.5114/hpr.2013.40469

[2] O'Connor D, Wolfe DM. From crisis to growth at midlife: Changes in personal paradigm. J Organization Behavior. 1991;12(4):323-40. https://doi.org/10.1002/job.4030120407

[3] Cooper KL, Gutmann DL. Gender identity and ego mastery style in middle-aged, pre- and post-empty nest women. Gerontologist. 1987;27(3):347-52. https://doi.org/10.1093/geront/27.3.347

[4] Lipowska M, Lipowski M, Olszewski H, Dykalska-Bieck D. Gender differences in body-esteem among seniors: Beauty and health considerations. Arch Gerontol Geriatrics. 2016;67(6):160-70.https://doi.org/10.1016/j.archger.2016.08.006

[5] Mohseni M, Iranpour A, Naghibzadeh-Tahami A, Kazazi L, Borhaninejad V. The relationship between meaning in life and resilience in older adults: A cross-sectional study. Health Psychol Rep. 2019;7(2):133-8. https://doi.org/10.5114/ hpr.2019.85659

[6] Demirci N, Demirci PT, Zırhlı O. The relationship between physical activity levels and health-related quality of life in elderly individuals aged 65 years and above with a chronic disease. Balt J Health Phys Act. 2020;12(3):103-13. https://doi.org/10.29359/BJHPA.12.3.10

[7] Daley A, Macarthur C, Stokes-Lampard H, McManus R, Wilson S, Mutrie N. Exercise participation, body mass index, and health-related quality of life in women of menopausal age. Br J Gen Pract. 2007;57(535):130-5.

[8] Brannon L. Gender: Psychological perspectives, 4th ed. Auckland, New Zealand: Pearson Education New Zealand; 2005.

[9] Jankowska AM, Łockiewicz M, Dykalska-Bieck D, Łada A, Owoc W, Stańczykowski D. Health behaviours in emerging adulthood: Their relationship with perceived maternal and paternal parental attitudes and the mediating role of selfefficacy. Health Psychology Report. 2018;6(1):94-108. https://doi.org/10.5114/hpr.2018.71202

[10] Lipowski M, Lipowska M, Jochimek M, Jurek P. Ex-athletes as parents promoting healthy lifestyles in their families: the nutrition and physical activity of mothers, fathers, and 6-year-old children. J Family Iss. 2021. https://doi. org/10.1177/0192513X20984501

[11] Lipowska M, Łada A, Lipowski M. Fathers' Coping and Children's Temperament as predictors of parental attitudes among Polish fathers. Men and Masculinity. 2021. https://doi.org/10.1177/1097184X20988897

[12] Lipowski M, Lipowska M, Jochimek M, Krokosz D. Resiliency as a factor protecting youths from risky behaviour: Moderating effects of gender and sport. Eur J Sport Sci. 2016;16(2):246-55. https://doi.org/10.1080/17461391.20 15.1024755

[13] García-Calvente Mdel M, Hidalgo-Ruzzante N, Del Río-Lozano M, Marcos-Marcos J, Martínez-Morante E, MarotoNavarro G, et al. Exhausted women, tough men: A qualitative study on gender differences in health, vulnerability and coping with illness in Spain. Sociol Health Illness. 2012;34(6):911-26. https://doi.org/10.1111/j.1467-9566.2011.01440.x

[14] Dewall CN, Bushman BJ, Giancola PR, Webster GD. The big, the bad, and the boozed-up: weight moderates the effect of alcohol on aggression. J Experiment Soc Psychol. 2010;46(4):619-23. https://doi.org/10.1016/j.jesp.2010.02.008

[15] Hunt G, Antin T. Gender and intoxication: From masculinity to intersectionality. Drugs. 2019;26(1):70-8. https://doi. org/10.1080/09687637.2017.1349733

[16] Berke DS, Leone R, Parrott D, Gallagher KE. Drink, don't think: The role of masculinity and thought suppression in men's alcohol-related aggression. Psychol Men Masculin. 2020;21:36-45. https://doi.org/10.1037/men0000199

[17] Peralta RL. College alcohol use and the embodiment of hegemonic masculinity among European American men. Sex Roles: A Journal of Research. 2007;56(11-12):741-56. https://doi.org/10.1007/s11199-007-9233-1

[18] Wells S, Flynn A, Tremblay PF, Dumas T, Miller P, Graham K. Linking masculinity to negative drinking consequences: the mediating roles of heavy episodic drinking and alcohol expectancies. J Stud Alcohol Drugs. 2014;75(3):510-9. https://doi.org/10.15288/jsad.2014.75.510

[19] Jakubowska H. Gra ciałem. Praktyki i dyskursy różnicowania płci w sporcie [Body in the game. Gender differentiation in sports - practice and discussions]. Warszawa: Wydawnictwo Naukowe PWN; 2014. Polish.

[20] Gentile A, Boca S, Giammusso I. 'You play like a Woman!' Effects of gender stereotype threat on Women's performance in physical and sport activities: A meta-analysis. Psychol Sport Exerc. 2018;39:95-103. https://doi.org/10.1016/j. psychsport.2018.07.013

[21] Jakubowska H. Are women still the 'other sex': Gender and sport in the Polish mass media. Sport in Society. 2015;18(2):168-85.

[22] Mroczkowska H. Płeć psychologiczna kobiet w zadaniach sportowych rodzajowo nieadekwatnych. Wychowanie Fizyczne i Sport. 2003;47(3):321-36.

[23] Kosakowska-Berezecka N, Besta T, Adamska K, Jaśkiewicz M, Jurek P, Vandello JA. If my masculinity is threatened I won't support gender equality? The role of agentic self-stereotyping in restoration of manhood and perception of gender relations. Psychol Men Masculin. 2016;17(3):274-84. https://doi.org/10.1037/men0000016 
[24] Kosakowska-Berezecka N, Korzeniewska L, Kaczorowska M. Sharing housework can be healthy: Cultural and psychological factors influencing men's involvement in household maintenance. Health Psychol Rep. 2016;4(3):189201. https://doi.org/10.5114/hpr.2016.62232

[25] Nowak PF, Barcicka P. Poziom zachowań zdrowotnych kieleckich licealistów [Level of health behaviors of senior high school students in Kielce]. Problemy Higieny i Epidemiologii. 2015;96:157-61. Polish.

[26] Walentukiewicz A, Łysak A, Wilk B. Uwarunkowania zdrowia gdańskich 18-latek-zachowania zdrowotne [Health conditioning of 18-year-old female students from Gdańsk - health attitudes]. Problemy Higieny i Epidemiologii. 2011;92(3):482-5. Polish. https://doi.org/10.2478/v10131-011-0011-7

[27] Michalski P, Wagner S, Andruszkiewicz A, Kosobucka A, Pietrzykowski Ł, Kubica A. Zróżnicowanie zachowań zdrowotnych, wartości osobistych i kryteriów zdrowia w zależności od płci wśród uczniów szkół ponadgimnazjalnych [Differences of health behaviours, personal values and health criteria related to high-school students gender]. Forum Medycyny Rodzinnej. 2016;10(4):219-28. Polish.

[28] Walentukiewicz A, Łysak A, Wilk B. Health behavior of nursing students. Nursing Problems /Problemy Pielęgniarstwa. 2013;21(4):484-8.

[29] Muszalik M, Kędziora-Kornatowska K, Marzec A, Klawe J. Analiza zachowań zdrowotnych, samooceny oraz zagrożeń zdrowia pielęgniarek studiujących zaocznie [Analysis of health behavior, self-rating of health and health hazards of external nursing students]. Problemy Higieny i Epidemiologii. 2007;88(3):354-9. Polish.

[30] Palacz J. Health behaviours of students in the light of selected conditioning. Med Og Nauk Zdr. 2014;20(3):301-6. https://doi.org/10.5604/20834543.1124662

[31] Zalewska-Puchała J, Majda A, Korzonek R. Zachowania zdrowotne i poczucie własnej skuteczności studentów w utrzymaniu zdrowia. Nursing Problems / Problemy Pielęgniarstwa. 2013;21(4):504-11. Polish.

[32] Muszalik M, Zielińska-Więczkowska H, Kędziora-Kornatowska K, Kornatowski T. Ocena wybranych zachowań sprzyjających zdrowiu wśród osób starszych w oparciu o Inwentarz Zachowań Zdrowotnych Juczyńskiego w aspekcie czynników socjo-demograficznych [Assessment of selected health behavior among elderly people in Juczyński's Inventory of Health Behavior regarding socio-demographic factors]. Problemy Higieny i Epidemiologii. 2007;94(3):50913. Polish.

[33] Zadworna-Cieślak M, Ogińska-Bulik N. Zachowania zdrowotne osób w wieku senioralnym - rola optymizmu [Health behaviors in the group of people in late adulthood period - the role of optimism]. Psychogeriatria Polska. 2013;10(4):145-56. Polish.

[34] Sygit-Kowalkowska E. Zachowania zdrowotne osób w okresie późnej dorosłości-socjodemograficzne korelaty i różnice między środowiskami społecznymi [The health behaviour of people in late adulthood - sociodemographic correlations and differences between social environments]. Annales Academiae Medicae Stetinensis. 2013;59(1):03-113. Polish.

[35] Nguyen H-HD, Ryan AM. Does stereotype threat affect test performance of minorities and women? A meta-analysis of experimental evidence. J Appl Psychol. 2008;93(6):1314-34. https://doi.org/10.1037/a0012702

[36] Gacek M. Zachowania żywieniowe i aktywność fizyczna w grupie lekarzy [Eating behaviors and physical activity in a group of physicians]. Problemy Higieny i Epidemiologii. 2011;92(2):254-9. Polish.

[37] Rothgerber H. Real men don't eat (vegetable) quiche: Masculinity and the justification of meat consumption. Psychol Men Masculin. 2013;14(4):363-75. https://doi.org/10.1037/a0030379

[38] Mioduchowska-Zienkiewicz A. Zachowania autoagresywne a obraz własnego ciała u kobiet z zaburzeniami odżywiania. Studia Psychologica: Theoria et praxis. 2017;1(15):45-62. Polish. https://doi.org/10.21697/sp.2015.15.01.04

[39] Izydorczyk B, Truong Thi Khanh H, Lipowska M, Sitnik-Warchulska K, Lizińczyk S. Psychological Risk Factors for the Development of Restrictive and Bulimic Eating Behaviors: A Polish and Vietnamese Comparison. Nutrients. 2021;13(3):910. https://doi.org/10.3390/nu13030910

[40] Keski-Rahkonen A, Mustelin L. Epidemiology of eating disorders in Europe: prevalence, incidence, comorbidity, course, consequences, and risk factors. Curr Opinion Psychiatr. 2016;29(6):340-5. https://doi.org/10.1097/ YCO.0000000000000278

[41] Udo T, Grilo CM. Prevalence and correlates of DSM-5-defined eating disorders in a nationally representative sample of U.S. adults. Biol Psychiat. 2018;84(5):345-54. https://doi.org/10.1016/j.biopsych.2018.03.014

[42] Springmann M-L, Svaldi J, Kiegelmann M. Theoretical and Methodological considerations for research on eating disorders and gender. Front Psychol. 2020;11. https://doi.org/10.3389/fpsyg.2020.586196

[43] Lipowska M, Lipowski M. Narcissism as a moderator of satisfaction with body image in young women with extreme underweight and obesity. Plos One. 2015;10(5):e0126724-e. https://doi.org/10.1371/journal.pone.0126724

[44] Holland G, Tiggemann M. 'Strong beats skinny every time': Disordered eating and compulsive exercise in women who post fitspiration on Instagram. Int J Eat Disord. 2017;50(1):76-9. https://doi.org/10.1002/eat.22559

[45] Izydorczyk B, Sitnik-Warchulska K, Lizińczyk S, Lipowska M. Socio-cultural standards promoted by the mass media as predictors of restrictive and bulimic behavior. Front Psychiatr. 2020;11(506). https://doi.org/10.3389/fpsyt.2020.00506

[46] Griffiths S, Murray SB, Touyz S. Extending the masculinity hypothesis: An investigation of gender role conformity, body dissatisfaction, and disordered eating in young heterosexual men. Psychol Men Masculin. 2015;16(1):108-14 https://doi.org/10.1037/a0035958

[47] Cella S, Iannaccone M, Cotrufo P. Influence of gender role orientation (masculinity versus femininity) on body satisfaction and eating attitudes in homosexuals, heterosexuals and transsexuals. Eat Weight Disord. 2013;18(2):11524. https://doi.org/10.1007/s40519-013-0017-z

[48] Davis JL, Buchanan KL, Katz RV, Green BL. Gender differences in cancer screening beliefs, behaviors, and willingness to participate: Implications for health promotion. Am J Men Health. 2012;6(3):211-7. https://doi. org/10.1177/1557988311425853

[49] Oster C, McGuiness C, Duncan A, Turnbull D. Masculinity and men's participation in colorectal cancer screening. Psychol Men Masculin. 2015;16(3):254-63. https://doi.org/10.1037/a0038154

[50] Christy SM, Mosher CE, Rawl SM. Integrating men's health and masculinity theories to explain colorectal cancer screening behavior. Am J Men Health. 2014;8(1):54-65. https://doi.org/10.1177/1557988313492171 
[51] Christy SM, Mosher CE, Rawl SM, Haggstrom DA. Masculinity beliefs and colorectal cancer screening in male veterans. Psychol Men Masculin. 2017;18(4):390-9. https://doi.org/10.1037/men0000056

[52] O'Brien R, Hunt K, Hart G. 'It's caveman stuff, but that is to a certain extent how guys still operate': men's accounts of masculinity and help seeking. Soc Sci Med. 2005;61(3):503-16. https://doi.org/10.1016/j.socscimed.2004.12.008

[53] Mayor E. Gender roles and traits in stress and health. Front Psychol. 2015;6(779). https://doi.org/10.3389/ fpsyg.2015.00779

[54] Bem SL. The measurement of psychological androgyny. J Consult Clin Psychol. 1974;42(2):155-62. https://doi. $\operatorname{org} / 10.1037 / \mathrm{h} 0036215$

[55] Pelletier R, Ditto B, Pilote L. A composite measure of gender and its association with risk factors in patients with premature acute coronary syndrome. Psychosom Med. 2015;77(5):517-26. https://doi.org/10.1097/ PSY.0000000000000186

[56] Pelletier R, Khan NA, Cox J, et al. Sex Versus Gender-Related Characteristics: Which Predicts Outcome After Acute Coronary Syndrome in the Young? J Am Coll Cardiol. 2016;67(2):127-35. https://doi.org/10.1016/j.jacc.2015.10.067

[57] EUGenMed, Cardiovascular Clinical Study Group, Regitz-Zagrosek V, et al. Gender in cardiovascular diseases: impact on clinical manifestations, management, and outcomes. Eur Heart J. 2015;37(1):24-34. https://doi.org/10.1093/ eurheartj/ehv598

[58] Mauvais-Jarvis F, Bairey Merz N, et al. Sex and gender: Modifiers of health, disease, and medicine. Lancet. 2020;396(10250):565-82. https://doi.org/10.1016/S0140-6736(20)31561-0

[59] Borchgrevink CP, Cha J, Kim S. Hand washing practices in a college town environment. Journal of environmental health. 2013;75(8):18-24.

[60] Sheehan CM, Frochen SE, Walsemann KM, Ailshire JA. Are U.S. adults reporting less sleep?: Findings from sleep duration trends in the National Health Interview Survey, 2004-2017. Sleep. 2019;42(2):zsy221. https://doi.org/10.1093/ sleep/zsy221

[61] Warren NB, Campbell TH. The sleep-deprived masculinity stereotype. Journal of the Association for Consumer Research. 2020;6(2):236-49. https://doi.org/10.1086/711758

[62] Burgard SA, Ailshire JA. Gender and Time for Sleep among U.S. Adults. Am Sociol Rev. 2013;78(1):51-69. https:// doi.org/10.1177/0003122412472048

[63] Soltani M, Haytabakhsh MR, Najman JM, et al. Sleepless nights: the effect of socioeconomic status, physical activity, and lifestyle factors on sleep quality in a large cohort of Australian women. Arch Women Mental Health 2012;15(4):237-47. https://doi.org/10.1007/s00737-012-0281-3

[64] Morris T, Roychowdhury D. Physical activity for health and wellbeing: The role of motives for participation. Health Psychol Rep. 2020;8(4):391-407. https://doi.org/10.5114/hpr.2020.100111

[65] Kim HJ, Oh SY, Lee DW, Kwon J, Park EC. The effects of intense physical activity on stress in adolescents: Findings from korea youth risk behavior web-based survey (2015-2017). Int J Environl Res Public Health. 2019;16(10). https:// doi.org/10.3390/ijerph16101870

[66] Bidzan-Bluma I, Lipowska M. Physical activity and cognitive functioning of children: A systematic review. International J Environ Res Public Health. 2018;15(4):800. https://doi.org/10.3390/ijerph15040800

[67] Telford RM, Telford RD, Olive LS, Cochrane T, Davey R. Why are girls less physically active than boys? findings from the LOOK longitudinal study. Plos One. 2016;11(3):e0150041-e. https://doi.org/10.1371/journal.pone.0150041

[68] Brazo-Sayavera J, Aubert S, Barnes JD, González SA, Tremblay MS. Gender differences in physical activity and sedentary behavior: Results from over 200,000 Latin-American children and adolescents. PloS One. 2021;16(8):e0255353-e. https://doi.org/10.1371/journal.pone.0255353

[69] Lipowski M. Rekreacja ruchowa kobiet jako zachowanie prozdrowotne - uwarunkowania a motywy uczestnictwa [Physical activity of women as pro-health behaviour - determinants and motives of participation]. Gdańsk: AWFiS; 2006.

[70] Hardin M, Greer JD. The Influence of Gender-role Socialization, Media Use and Sports Participation on Perceptions of Gender-Appropriate Sports. Journal of Sport Behavior. 2009;32(2):207-26.

[71] Matteo S. The effect of sex and gender-schematic processing on sport participation. Sex Roles: A Journal of Research. 1986;15(7-8):417-32. https://doi.org/10.1007/BF00287981

[72] Burdzicka-Wołowik J. Psychological gender of women taking up typically masculine sports activity. Biomedical Human Kinetics. 2012;4(2012):24-8. https://doi.org/10.2478/v10101-012-0005-1

[73] Wilczyńska D, Bastian P, Jagodzka A, Owczarek A, Graczyk M. Samoocena ciała i płeć psychologiczna u zawodniczek uprawiających różne dyscypliny sportu [Body image self-assessment and psychological gender among female athletes competing in different sports]. Rocznik Naukowy AWFiS. 2016;26:5-9. Polish.

[74] Bojkowski Ł. Płeć psychologiczna osób biorących udział w aktywności sportowej [Gender of people involved in sports activities]. Polski Przegląd Nauk o Zdrowiu. 2013;31(1):52-6. Polish.

[75] Bojkowski Ł, Kalinowski P. Psychological gender of sportsmen in team sports. Trends Sport Sci. 2019;26(3):113-6.

[76] Austad SN. Why women live longer than men: Sex differences in longevity. Gender Med. 2006;3(2):79-92. https:// doi.org/10.1016/S1550-8579(06)80198-1

[77] Plant EA, Hyde JS, Keltner D, Devine PG. The Gender stereotyping of emotions. Psychol Women Q. 2000;24(1):81-92. https://doi.org/10.1111/j.1471-6402.2000.tb01024.x

[78] Matud MP. Gender differences in stress and coping styles. Personal Indiv Differ. 2004;37(7):1401-15. https://doi. org/10.1016/j.paid.2004.01.010

[79] Reiche EM, Nunes SO, Morimoto HK. Stress, depression, the immune system, and cancer. Lancet Oncol. 2004;5(10):61725. https://doi.org/10.1016/S1470-2045(04)01597-9

[80] Soung NK, Kim BY. Psychological stress and cancer. J Analytical Sci Technol. 2015;6(1):30. https://doi.org/10.1186/ s40543-015-0070-5

[81] Stefanaki C, Pervanidou P, Boschiero D, Chrousos GP. Chronic stress and body composition disorders: Implications for health and disease. Hormones (Athens, Greece). 2018;17(1):33-43. https://doi.org/10.1007/s42000-018-0023-7 
[82] Iob E, Steptoe A. Cardiovascular Disease and Hair Cortisol: a Novel Biomarker of Chronic Stress. Curr Cardiol Rep. 2019;21(10):116-. https://doi.org/10.1007/s11886-019-1208-7

[83] Stroud CB, Davila J, Moyer A. The relationship between stress and depression in first onsets versus recurrences: A meta-analytic review. J Abnorm Psychol. 2008;117(1):206-13. https://doi.org/10.1037/0021-843X.117.1.206

[84] van Winkel R, Stefanis NC, Myin-Germeys I. Psychosocial stress and psychosis. A review of the neurobiological mechanisms and the evidence for gene-stress interaction. Schizophrenia Bull. 2008;34(6):1095-105. https://doi. org/10.1093/schbul/sbn101

[85] Lipińska-Grobelny A. Effects of gender role on personal resources and coping with stress. Int J Occup Med Environ Health. 2011;24(1):18-28. https://doi.org/10.2478/s13382-011-0002-6

[86] Cabras C, Mondo M. Coping strategies, optimism, and life satisfaction among first-year university students in Italy: Gender and age differences. Higher Educ. 2018;75:643-54. https://doi.org/10.1007/s10734-017-0161-x

[87] Puskar KR, Marie Bernardo L, Ren D, Haley TM, Hetager Tark K, Switala J, et al. Self-esteem and optimism in rural youth: Gender differences. Contemp Nurse. 2010;34(2):190-8. https://doi.org/10.5172/conu.2010.34.2.190

[88] Nolen-Hoeksema S. Sex differences in unipolar depression: Evidence and theory. Psychological Bulletin. 1987;101(2):259-82. https://doi.org/10.1037/0033-2909.101.2.259

[89] Nolen-Hoeksema S, Hilt LM. Gender differences in depression. 2009. In: Handbook of depression, 2nd ed [Internet]. New York, NY, US: The Guilford Press, 386-404.

[90] Szpitalak M, Prochwicz K. Płeć psychologiczna osób z depresją kliniczną. Doniesienia wstępne [Psychological gender in clinical depression. Preliminary study]. Psychiatria Polska. 2013;47(1):53-64. Polish.

[91] Yousaf O, Popat A, Hunter MS. An investigation of masculinity attitudes, gender, and attitudes toward psychological help-seeking. Psychol Men Masculin. 2015;16(2):234-7. https://doi.org/10.1037/a0036241

[92] McCusker MG, Galupo MP. The impact of men seeking help for depression on perceptions of masculine and feminine characteristics. Psychol Men Masculin. 2011;12:275-84. https://doi.org/10.1037/a0021071

[93] WHO. World Health Organization guidelines on physical activity and sedentary behaviour. Geneva 2020

[94] Kuczyńska A. Inwentarz Płci Psychologicznej. Podręcznik. [Psychological Gender Inventory. Manual]. Warszawa: Pracownia Testów Psychologicznych PTP; 1992. Polish.

[95] Juczyński Z. Narzędzia pomiaru w promocji i psychologii zdrowia [Instruments for measurements in health promotion and psychology]. Warsaw: Pracownia Testów PTP; 2001. Polish.

[96] Lipowski M, Zaleski Z. Inventory of Physical Activity Objectives - A new method of measuring motives for physical activity and sport. Health Psychol Rep. 2015;3(1):47-58. https://doi.org/10.5114/hpr.2015.49462

[97] Bem SL. Gender schema theory: A cognitive account of sex typing. Psychol Rev. 1981;88(4):354-64. https://doi. org/10.1037/0033-295X.88.4.354

[98] Lipowski M, Ussorowska A. The motivational function of an objective in physical activity and sport. Curr Iss Personal Psychol. 2018;6(1):57-66. https://doi.org/10.5114/cipp.2018.72054

[99] Wojciechowska M, Ewa I. Prophylaxis of arterial hypertension. Med Og Nauk Zdr. 2014;20(4):370-3. https://doi. org/10.5604/20834543.1132038

[100] Boguszewski D, Andersz N, Janicka M, Mrozek N, Nowakowski PA, Adamczyk JG, et al. Assessment of health-related behaviors of women and men practicing basketball. J Health Sci. 2014;4(5):41+6.

[101] Litwic-Kaminska K, Izdebski P. The concept, subjective health assessment, health behaviours and physical activity level in early adulthood. Pol J Sport Med. 2012;20(3):167-78. https://doi.org/10.5604/1232406X.1023265

[102] Delisle TT, Werch CE, Wong AH, Bian H, Weiler R. Relationship between frequency and intensity of physical activity and health behaviors of adolescents. J School Health. 2010;80(3):134-40. https://doi.org/10.1111/j.17461561.2009.00477.x

[103] Loumidis K, Wells A. Exercising for the wrong reasons: relationships among eating disorder beliefs, dysfunctional exercise beliefs and coping. Clin Psychol Psychother. 2001;8(6):416-23. https://doi.org/10.1002/cpp.298

[104] Morga P, Traczyk J, Wittenbeck K, Zygmont A. Review of research on the impact of physical activity on mental state of the elderly. Fizjoterapia. 2015;23(2):42-51. https://doi.org/10.1515/physio-2015-0008

[105] Schuch FB, Vancampfort D, Firth J, et al. Physical activity and incident depression: A meta-analysis of prospective cohort studies. Am J Psychiatry. 2018;175(7):631-48. https://doi.org/10.1176/appi.ajp.2018.17111194

[106] Lefkowitz ES, Zeldow PB. Masculinity and femininity predict optimal mental health: A belated test of the androgyny hypothesis. J Pers Assess. 2006;87(1):95-101. https://doi.org/10.1207/s15327752jpa8701 08

[107] Juster RP, Pruessner JC, Desrochers AB, et al. Sex and gender roles in relation to mental health and allostatic load. Psychosom Med. 2016;78(7):788-804. https://doi.org/10.1097/PSY.0000000000000351

[108] Brinkman BG, Khan A, Edner B, Rosén LA. Self-objectification, feminist activism and conformity to feminine norms among female vegetarians, semi-vegetarians, and non-vegetarians. Eating Behav. 2014;15(1):171-4. https://doi org/10.1016/j.eatbeh.2013.11.006

[109] Lipowska K, Łada-Maśko AB. When parents go shopping: Perspectives on gender-typed toys among polish mothers and fathers from big cities. Children. 2021;8(9):744. https://doi.org/10.3390/children8090744

[110] Moore SC, Patel AV, Matthews CE, et al. Leisure time physical activity of moderate to vigorous intensity and mortality: A large pooled cohort analysis. PLoS Med. 2012;9(11):e1001335. https://doi.org/10.1371/journal.pmed.1001335 